\title{
The Eastern Partnership and the EU-Turkey Energy Relations
}

\author{
Tolga Demiryol \\ Department of Political Science \\ and Public Administration, \\ Istanbul Kemerburgaz University \\ Mahmutbey Dilmenler Caddesi, No. 26, \\ Bağcılar 34217, İstanbul, Turkey \\ E-mail: tolga.demiryol@kemerburgaz.edu.tr
}

Abstract: This article discusses the prospects and challenges of energy cooperation between the European Union (EU) and Turkey within the context of the Eastern Partnership (EaP). Part of the EaP agenda is to advance energy cooperation between the EU and the partner states, particularly regarding the diversification of import routes. As an energy corridor between the EU and the hydrocarbon-rich Caspian states, Turkey is a strategic asset for European energy security. Turkey also has economic ties and political capital in the Caspian region that can help the EU reach out to its eastern partners. Despite robust incentives for cooperation, however, the EU-Turkey energy partnership has so far failed to meet mutual expectations. This article argues that this is primarily due to the inability of the two actors to credibly commit to regional energy cooperation. Commitment problem stems from two factors. First, the predominance of national energy interests over communal ones undermines credible commitment. The variation in energy needs of Member States prevents the EU from acting in unison in external energy policy. Similarly, Turkey also prioritizes its own energy security, particularly in its relations with suppliers, which undermines cooperation with the $E U$. Second, the EU and Turkey hold divergent perspectives on the potential political payoffs of energy cooperation. Turkish decision makers are convinced that energy cooperation warrants palpable progress in Turkey's accession while most EU actors appear hesitant to establish a direct connection between energy and accession.

Keywords: Eastern Partnership, energy security, the European Union, Turkey 


\section{Introduction}

What role does energy security play in the Eastern Partnership (EaP)? How can Turkey, as a regional partner to both the EU and most EaP countries, contribute to the energy platform of the EaP? This article discusses the prospects and challenges of EU-Turkish energy cooperation within the context of the EaP.

Turkey's relevance to the energy initiatives of the EaP in part stems from Turkey's geopolitical position as an energy corridor (Bilgin, 2010; MüftülerBaç \& Başkan, 2011; Roberts, 2003; Winrow, 2013). Turkey is located between the rich hydrocarbon reserves in the Caspian region and the European markets and thus sits at the intersection of the most feasible energy transit lines. Yet, geopolitics is not the only reason why Turkey is relevant to the EU's energy interests in the Caspian. Turkey also has significant political capital and economic ties in the Caspian region that the EU can capitalize on to achieve its long-term energy policy objectives. Despite the fact that the EU and Turkey have a shared interest in energy security, there are at least two major obstacles that have so far prevented the EU and Turkey from effectively coordinating on energy policy.

First, the dissimilar and at times incompatible energy interests of the EU members undermine the EU's capacity to implement a common external energy policy. Unable to speak in one voice, the EU sends mixed signals to its regional partners, including Turkey. Similarly, Turkey tends to prioritize its own shortterm national energy interests over the long-term benefits from cooperation with the EU. The prevalence of national interests over communal ones thus generates a credible commitment problem between the EU and Turkey, where parties are unable to make binding promises for cooperation. For the EU and Turkey to establish a working partnership on energy issues, they should arrive at a common understanding whereby each actor not only values long-term cooperation over short-term interests but also trusts that the other side will do the same.

Second, the commitment issue is aggravated by the apparently mismatched perspectives that the EU and Turkey adopt on the political implications of energy cooperation. Turkish decision makers hold that Turkey's position as an energy corridor merits tangible political benefits, most notably concrete progress in Turkey's accession talks. Even though most EU officials acknowledge that Turkey could be a strategic asset for European energy security, few go so far as to establish a direct issue-linkage between energy and membership. The discordancy of the EU's and Turkey's expectations regarding the political 
payoffs of energy cooperation undermines the mutual trust that is required for long-term partnership.

The article consists of two main parts. Part One reviews the rising significance of energy security in the EU's major regional initiatives in the last two decades, culminating in the establishment of the EaP and its energy agenda in 2009. This part also elaborates on Turkey's potential contribution to European energy security. Part Two discusses the major obstacles in front of comprehensive energy cooperation between the EU, Turkey and the EaP. The concluding section summarizes the arguments and offers final remarks.

\section{The significance of energy security in Eastern Partnership and Turkey's role}

The EaP was introduced as a joint Polish-Swedish initiative in May 2008. The initiative was conceived as a venue for dialogue and cooperation between the EU and the former Soviet states of Armenia, Azerbaijan, Belarus, Georgia, Moldova, and Ukraine. The Joint Declaration of the Prague Eastern Partnership Summit, signed on 7 May 2009, stated that the "main goal of the Eastern Partnership is to create the necessary conditions to accelerate political association and further economic integration between the European and interested partner countries" (European Union, 2009). Through the implementation of Association Agreements, the EaP aims to facilitate the social, economic, and political transformation in the six partner states.

The EaP is a multi-dimensional directive, yet energy security has been at the core of the partnership since its inception. The Prague Declaration says, "The eastern partnership aims to strengthen energy security through cooperation with regard to long term stable and secure energy supply and transit, including through better regulation, energy efficiency and more use of renewable energy sources" (European Union, 2009). Energy security is one of the four thematic platforms of the EaP, along with democracy and good governance, economic integration and contacts with people. Two of the six flagship initiatives of the $\mathrm{EaP}$ are also energy-related. One of these initiatives concerns the integration of regional energy markets and raising the profile of renewable energy in partner states, whereas the other initiative directly involves the diversification of energy import routes. On 8 May 2009, the very next day following the EaP Summit, the Southern Corridor Summit was held in Prague, where European Commission officials as well as the presidents of Azerbaijan, Georgia, and Turkey, expressed 
their "political support to the realization of the Southern Corridor as an important and mutually beneficial initiative" (EU at the UN, 2009). Jose Manuel Barroso, President of the European Commission, speaking at the summit, underlined that diversification was indeed a priority: "The context of this summit is very clear. Our strategic priority in the EU is to enhance energy security in particular by diversifying the EU's energy sources and energy routes" (Barroso, 2009).

At the core of the EU's diversification strategy is the development and integration of multiple pipeline systems under the general framework of the Southern Gas Corridor, which would carry gas to Europe primarily from the Caspian region (possibly from Turkmenistan, Iran, and the Middle East as well), bypassing transit networks owned or controlled by Russia. This grand energy strategy can be traced back to the establishment of INOGATE (Interstate Oil and Gas transport to Europe) in 1995. INOGATE was later expanded through the signing of umbrella agreements in 2001 when 21 countries agreed to cooperate on pipeline development. Through conferences in Baku in 2004 and in Astana in 2006, INOGATE evolved into the primary institutional framework of regional cooperation on energy security and integration of markets. The next major step in building the institutional framework of a European energy policy was the signing of Energy Community Treaty, which entered into force in July 2006, establishing an Energy Community among the EU members as well as Albania, Bosnia and Herzegovina, Kosovo, Montenegro, Macedonia, Serbia, Moldova, and Ukraine. Yet another landmark was the Treaty of Lisbon in 2007, which included an article on energy policy, calling for solidarity among Member States. In February 2010, the European Commission established a new DirectorateGeneral for Energy, further indicating the significance attached to the issue. The EaP's energy agenda should thus be considered the latest step in the evolution of EU's long-standing efforts to resolve the energy security problem.

How severe is the energy security problem of the EU? Europe is an energy-poor region. It possesses only 0.4 per cent of the world's proved oil reserves but consumes 15.9 per cent. Similarly, 0.9 per cent of world's natural gas reserves are in Europe while European consumption constitutes 13.9 per cent of the global consumption (BP, 2012). Not only are the hydrocarbon reserves limited but also production is falling. Total energy production in the EU declined by 13 per cent over the last 20 years. Natural gas production in Europe is in decline. Since 2001, EU-28's natural gas production decreased by 38 per cent while consumption was reduced by only about 7 per cent. This unfavorable supply and demand structure inevitably led to greater import dependency. Europe's total energy import dependency rose from 47.1 per cent in 2001 to 53.4 per cent in 2012. Europe imports 90 per cent of its oil and 42 per cent of its solid fuels, 
yet gas dependency is the most alarming. Gas import dependency jumped from 48.8 per cent in 2001 to 65.8 per cent in 2012 (Eurostat, 2014).

EU is following a multifaceted energy security strategy (European Commission, 2014a,b). The union is committed to reducing primary energy consumption by 20 per cent by 2020 (European Commission, 2011). The energy saving measures are helpful but ultimately insufficient to compensate for the decline in production. In 2012, natural gas consumption in Europe declined 9.9 per cent while production fell by 11.4 per cent. It is possible that part of the decline in energy consumption over the past few years is due to the contraction of the European economy since 2008. With economic restoration over the next decade, energy demand will likely increase, unless policy changes produce significant changes in the structure of energy consumption.

Indeed, projections for EU's natural gas demand for the two decades indicate significant variations based on policy environment and expectations regarding macro-economic performance. According to Eurogas' Base Case, which assumes no significant departure from current policy and market conditions, EU-27's natural gas demand will increase from $438 \mathrm{mtoe}$ (million tonnes of oil equivalent) in 2010 to 471 mtoe in 2035 (Eurogas, 2013, p. 3) In the Environmental Case, which assumes a growing share of renewables and a restoration of economic growth in Europe, demand for natural gas will rise to 527 mtoe by 2035, a 20 per cent increase over the 2010 baseline. Only under the Slow Developments Case, which assumes that gas would become less competitive in Europe, will demand decline to 394 mtoe by 2035 (Eurogas, 2013, p. 3). Thus, barring a significant change in policy and market conditions, natural gas will likely remain a key source of energy for Europe over the next two decades.

Similarly, a report published by Fitch Ratings in August 2014 confirmed that Europe will continue to depend on Russian gas supplies "for at least the next decade and potentially much longer" (Fitch Ratings, 2014). According to Fitch Rating's projections, European gas demand will grow slightly until the mid-2020s and after that, demand growth will once again accelerate as gas-fired electricity generation replaces coal and nuclear capacity. European shale gas, the report indicates, will not be a viable option for another decade when production reaches a critical volume. Even then, shale gas production would most likely be just enough to compensate for the decline in domestic conventional gas production in Europe. The best the EU can hope for, the report concludes, is to avoid significantly increasing gas purchases from Russia. (Fitch Ratings, 2014) 
Thus, energy import dependency will likely continue to be a major issue for Europe. Dependency, particularly on a single supplier, is considered a source of economic and political vulnerability in international relations (Waltz, 1970). Dependent countries are highly vulnerable to supply disruptions whether they are of technical or political nature. The 2006 and 2009 gas shortages in Ukraine and 2007 crisis involving Belarus served as bitter reminders that import dependency threatens the material well-being and security of ordinary citizens. Import dependency has negative consequences on the foreign policy capabilities of the dependent country as well. The potential cost of aggravating an energy supplier casts the dependent actor into an involuntarily cooperative role. Foreign policy implications of energy dependency are particularly relevant when the energy exporters are keen on using their market power as a weapon over importers and transit countries (Gereben, 2013; Stegen, 2011). Ukraine Crisis in 2014 evidenced the extent to which energy dependence constrains EU foreign policy.

Given the political and economic costs of energy dependency, the EU has no choice but to seek to diversify its energy suppliers and import routes. The EU has a few alternative natural gas suppliers, including Iraq, Iran and most recently Eastern Mediterranean but none of these alternatives appears to be as readily accessible as the Caspian reserves in the near future. Iraqi natural gas reserves rank $12^{\text {th }}$ in the world (EIA, 2013) but given various infrastructure issues and the continuing political turmoil in the country, Iraq's natural gas export capacity is currently limited. Importing natural gas from Iran has long been on the agenda of the EU and the most recent problems with the availability of Russian gas have once again brought the issue to the forefront (The Telegraph, 2014). Most European countries are looking forward to the normalization of relations with Tehran, as evidenced most recently by UK's plans to reopen its embassy in Tehran (Foreign \& Commonwealth Office, 2014). With a treasury badly damaged by the international sanctions, Iran too would be most interested in selling its gas to Europe, arguably more so than selling to Pakistan (Forbes, 2014). While Iranian natural gas reserves, estimated to be the second largest in the world, constitute a viable alternative for Europe, accessing these reserves poses a challenge in the short term. Even if the ongoing negotiations between P5+1 and Iran ultimately succeed in lifting the sanctions on Iranian energy trade, Iran's South Pars gas reserves require significant development and investment over the next decade. Once developed and rendered available for international trade, Iranian natural gas will likely be transported to Europe via the proposed Persian Pipeline (Iran-Europe pipeline) 
or possibly a re-animated Nabucco pipeline, ${ }^{1}$ both of which are projected to pass through Turkey. Recently discovered gas in the Eastern Mediterranean would also be a welcome addition to Europe's energy portfolio yet given the disputes over maritime borders in the region (Eissler \& Aras1l, 2014), the enduring Cyprus problem and the lingering hostilities between Turkey and Israel since 2010, it is unclear if Eastern Mediterranean gas will ever be available for European consumption in any significant quantities (Antreasyan, 2013; Emerson, 2013; Iseri \& Andrikopoulos, 2013; Khadduri, 2012).

Given the various political and economic limitations of bringing online the natural gas from Iraq, Iran and the East Mediterranean in the near term, the Caspian region - estimated to hold six per cent of the world's proven reserves and well-endowed with foreign investment - currently appears to be the most politically and economically feasible option for European diversification strategy.

The Southern Gas Corridor linking Caspian reserves to European markets consists of several existing and projected pipelines. The Baku-Tbilisi-Erzurum (BTE) gas pipeline carries gas from Shah Deniz gas field in the Azerbaijani sector of the Caspian Sea to Turkey since late 2006. The current capacity of the pipeline is $8 \mathrm{bcma}$ (billion cubic meters per annum) but with the completion of the phase II of the Shah Deniz project it can be scaled up to $25 \mathrm{bcma}$. BTE currently supplies Georgia and Turkey but it can be linked to other projects like the Trans-Anatolian Pipeline (TANAP) which will initially carry about $16 \mathrm{bcma}$ of gas from Georgian-Turkish border to Turkish-European border. Depending on the gas flow, the capacity of the pipeline can later be increased up to $60 \mathrm{bcma}$.

There are several options to further transport the Caspian gas from Turkish territory to European markets. The primary existing route is the Turkey-Greece Interconnector, which carries up to 12 bcma of natural gas. A key aspect of this project is the extension across Greece to Italy, which will carry Caspian gas deeper into Europe. A few additional routes to transport Caspian gas from Turkey to Europe have been considered. Nabucco West, the revised version of the defunct Nabucco project, was planned to start from the Turkish-Bulgarian border and transport gas from Shah Deniz Gas field phase II via Bulgaria, Romania, Hungary to Austria. Yet Shah Deniz Consortium partners rejected

1 Following the Ukraine crisis, Nabucco has once again appeared on the agenda as a possible route to carry Iranian gas to Europe. During negotiations with European officials in August 2014, Iranian Deputy Minister for Oil Ali Mejidi has reportedly pointed to Nabucco as the most feasible route to carry Iranian gas to Europe (The Bosnia Times, 2014). 
Nabucco West in 2013 and opted for the Trans-Adriatic Pipeline (TAP) instead. The main supply source of TAP will be the gas extracted from phase II of the Shah Deniz field, which will be carried through Turkish territory via BTE and TANAP. TAP is planned to start at Greece, cross Albania and the Adriatic to reach Italy.

Turkey thus sits at the intersection of the pipelines that constitute the Southern Gas Corridor. Turkey's relevance to the EU's energy policy with respect to Eastern Partnership, however, is not limited to Turkey's fortunate geopolitical position. Secure and reliable access to Caspian hydrocarbon reserves requires not only a network of pipelines but also regional political stability and cooperation between supplier and transit states. Turkey, with its long-standing economic ties in the Caspian region can potentially act as an intermediary between the $\mathrm{EU}$ and the partner countries. Turkey has also been willing to contribute to the resolution of the several "frozen conflicts" throughout the region by acting as an interlocutor between the EU, Russia and other relevant parties.

Ankara has a standing policy of promoting interdependence among the three South Caucasus states in order to expand their trade and energy ties with Turkey. Georgia is not only a transit corridor of Azerbaijan's gas, but also a major trade route for Turkish exports to Central Asia. Turkey also has considerable investments in Azerbaijan, Georgian and Abkhazian economies. Pending on the normalization of relations with Armenia and the opening of the Turkish-Armenian border, economic relations with Armenia also hold great promise for Turkey. Turkey can also help the EU in its capacity building efforts in the Caspian region. Turkish state-owned energy companies TPAO and BOTAS are partners in many pipeline projects in the region. Turkey has also recently shown a great deal of interest in investing in upstream development projects in the region. TPAO for instance signed in May 2014 a 1.5 billion USD deal to acquire French Total's 10 per cent stake in Azerbaijan's Shah Deniz project. In addition to Shah Deniz, TPAO owns shares in the two major fields in Azerbaijan, ACG (6.75\%) and Alov (9\%). Turkey has a strong presence on the ground and Turkish private sector accumulated expertise that is critical for secure and long-term cooperation.

Lastly, Turkey due to its historic ties to the region has considerable political capital in the Caspian, particularly in Azerbaijan, with which Turkey has sustained a very close relationship since its independence. Turkey also cooperated with the US in its efforts to help Georgia build a new state after independence. Given the difficulties that the EU has experienced in politically reaching out to its Caspian partners over the last decade, the EU can benefit from Turkey's role as a regional interlocutor between Europe and the Caspian partners. 
It is evident that the EU and Turkey can both benefit from extending their cooperation on regional energy issues. Despite the commonality of interests, however, EU-Turkey energy cooperation has so far failed to meet mutual expectations. The next section examines how the prevalence of national interests over communal ones and the opposing views on the Turkish and European sides regarding the political implications of energy partnership undermine the ability of these two actors to commit to a more extended form of energy cooperation.

\section{The limits of regional energy cooperation}

It is an often voiced criticism that the EU lacks a common energy policy (Pointvogl, 2009; Youngs, 2011), which is perhaps ironic given that energy issues have been at the core of the union since its inception. Two of the founding treaties of the European Communities are about energy: the European Coal and Steel Community (ECSC) Treaty and the Euratom Treaty. These treaties however were conceived primarily to secure the supply of coal and nuclear energy; a common energy policy was not part of the agenda. Neither did the Maastricht and Amsterdam Treaties include a chapter on energy. While the beginnings of a European energy transit policy can be traced back to INOGATE in 1995, it was in the mid-2000s when a serious debate within the EU began to take place regarding the need for a common and comprehensive energy policy. Since then, calls for common external energy policy have been heard more frequently in the EU policy circles (European Commission, 2006; 2008). Treaty of Lisbon of 2007 introduced a specific legal basis for common energy policy with Article 194, which declared that all Member States should be in solidarity to ensure the security of energy supply in the union. The need for coordination among all EU members was underlined in the European Commission's 2011 document, Energy 2020-A strategy for Competitive, Sustainable and Secure Energy which stated, "the EU must now formalize the principle whereby Member States act for the benefit of the EU as a whole in bilateral relations with key partners and in global discussions" (European Commission, 2011, p. 21).

Despite the realization that coordinated action is needed, the EU still struggles to act in unison on energy issues. This failure can be partially explained by the stark differences in the determinants of national energy policies in Member States, particularly the varying rates of import dependency. The average rate of dependency on imported gas is at 65.8 per cent for the EU-28, yet the degree and nature of dependency varies considerably across members. Only a couple of 
countries - Denmark and Netherlands - produce more than they consume even though Netherlands imports about 8 per cent of its gas from Russia. These relatively self-sufficient countries have insufficient incentives to invest in a common energy policy. Others are dependent on imports to varying degrees. Dependency on gas imports is nearly 100 per cent in Spain and France, 90 per cent in Italy, 85 per cent in Germany and about 47 per cent in the UK (Eurostat, 2014).

Yet another source of variation among dependent countries is the source of imports. Russia (along with Norway) is the primary supplier of gas to Europe but not all EU members are dependent on Russian gas. Spain and the UK do not rely on Russia as much as others do, and thus can be expected to have weaker incentives to support diversification efforts intended to bypass Russian transit networks. Spain purchases most of its gas though LNG (Liquefied Natural Gas) imports from Algeria, Nigeria, and Qatar. The UK primarily imports from Norway and Qatar. France and Italy import less than 17 per cent of their gas from Russia. Belgium, Cyprus, Ireland, Luxembourg, Malta, Portugal, and Sweden are also among the countries that do not import gas from Russia in any significant quantities. In contrast, Bulgaria, Estonia, Finland, Latvia, Lithuania, and Slovakia are 100 per cent dependent on Russian gas. Dependency rate on Russian gas is similarly high in Austria (62.5\%), Czech Republic (71.9\%), Greece (52.8 \%), Hungary (65\%), Poland (62.3\%), and Slovenia (56.2 \%) (Belkin et al., 2012, p. 10). The average rate of dependency on Russian gas was 27 per cent in 2012 (Fitch Ratings, 2014).

Market size is yet another factor that creates a conflict of interest among states that are dependent on imports. Countries with larger natural gas imports have an advantage that energy-dependent countries with smaller markets lack: bargaining power vis-à-vis suppliers. By the sheer size of their markets, energy consumers like Germany can negotiate on prices and contractual terms, whereas the smaller yet energy-dependent economies in the Baltics and Central Europe do not possess comparable bargaining power. The national energy policies of the states with greater market power can undermine the interests of the other dependent countries. Germany, for instance, spearheaded the Nord Stream project, which consists of two parallel pipelines through the Baltic Sea to carry Russian natural gas to Germany. Nord Stream has widely been criticized in Europe because it would increase Europe's dependence on Russian imports. Yet Germany, which imports more than 40 per cent of its gas from Russia, has a stake in securing its own direct access to these supplies. Seen in this light, Germany's national energy interests diverge from those of the union, or at least those EU members who are dependent on Russian natural gas but do not have the bargaining power that Germany and other major importers have. 
The dependent countries with limited market power deal with their suppliers on a bilateral basis. Throughout 2008 and 2009, several EU countries signed bilateral Intergovernmental Agreements with Russia to become partners in Russia's South Stream pipeline, which will transport Russian gas through the Black Sea and the Balkans to Italy. By signing agreements with Russia to build and operate parts of South Stream pipeline in their own territories, Serbia, Hungary, Slovenia, Austria and other project partners acted on their own national energy interests, even though South Stream was clearly in competition with Nabucco project, supported by the European Commission. In fact, many critics hold that the primary strategic goal of South Stream was to undermine Nabucco and Southern Gas Corridor by coopting European countries into investing into an alternative pipeline owned and controlled by Russia (Baran, 2008). Russia also used both South and Nord Stream projects to put pressure on Caspian suppliers and effectively reduce the amount of gas available for non-Russian pipelines (IEA, 2008, p. 14).

Yet another factor that complicates energy policy-making is the interests of major European energy companies, several of which have partnerships with Russian energy giants like Gazprom and Rosneft. Norway's Statoil, for instance, recently partnered with Rosneft to search for oil in the Arctic, despite the international sanctions on Moscow as of August 2014 (BBC News, 2014). BP, which owns 20 per cent of Rosneft, similarly declared that they do not intend to cease their business dealings in Russia (The Guardian, 2014). Italy's ENI is one of Gazprom's major partners in South Stream. Germany's E.ON and Wintershall, Netherland's Gasunie and France's GDF are among the partners of Nord Stream, along with Russia's Gazprom. The interests of these major European energy companies in the continuation of energy interdependence with Russia, is one of the main factors why it is rather difficult for the EU to formulate and implement a unified external energy policy, particularly one that seeks to reduce EU's dependence on Russian gas.

It is not only European countries that favor national over collective interests in external energy policy. Turkey too operates under conditions of heavy reliance on natural gas imports, which incentivizes Ankara to prioritize its own shortterm energy interests over the long-term objectives shared with the EU. As a growing economy, Turkey's energy demand rises about six per cent annually. Turkey currently imports about 75 per cent of its energy. Natural gas is the fastest growing energy source in Turkey; the share of natural gas in total primary energy consumption increased from six per cent in 1990 to over 17 per cent in 2000 and 35 per cent in 2011. Turkey's gas demand is expected to reach 76 bcma in 2030, a more than 50 per cent increase from the current level. Turkey is 
99 per cent dependent on gas imports and more than 55 per cent of the imports originate from Russia (Directorate of Natural Gas Markets, 2012).

Even though Turkey and the EU have common incentives in energy transit, the priority of Turkish government is to meet its own energy needs (BOTAS, 2011). An example of this preference was Turkey's attitude towards South Stream and Nabucco. Turkey initially did not fully endorse South Stream in order not to jeopardize relations with the EU. Russia however needed Turkey's support, as the most feasible route for the pipeline went through Turkey's maritime Economic Exclusive Zone in the Black Sea. Seeing an opportunity for boosting its short-term energy security, Ankara demanded lower prices and more flexible take-or-pay arrangements from Moscow. After lengthy negotiations throughout 2011, Turkey finally issued the permit to Russia in return for some concessions from Moscow (Kardaş, 2012; Kim \& Blank, 2012; Sidar \& Winrow, 2011). By agreeing to endorse Russia's South Stream, Turkey not only undermined Nabucco, but also signaled to the EU that when faced with a choice between its short-term goal of securing access to energy at better terms and its long-term commitment to the EU, Turkey would opt for the former.

The problem of credible commitment in Turkish-European energy relations is further exacerbated by the different positions that Turkish and European decision makers take on the issue of whether Turkey's role as an energy transit state should have any impact on Ankara's bid for EU membership. Turkish officials firmly believe that there is a clear linkage between energy security and accession. Commenting on Turkey's role in Nabucco, Turkish Minister of Energy and Natural Resources Taner Yildiz said, for instance, "With Nabucco, we believe we deserved the EU" (Haberler, 2009). Deputy Undersecretary Yazar echoed this sentiment when he wrote, "The 'energy corridor' role has strengthened Turkey's position in the accession period" and "the EU must shorten and ease the accession period to guarantee both the realization and operation of this energy corridor" (Yazar \& Erkaya, 2007, p. 18). Turkish side has the perception that the EU is unwilling to make any meaningful progress in the accession negotiations, despite Turkey's efforts to contribute to European energy security. Turkish decision makers are convinced that the strategic value of Turkey for European energy security is beyond doubt and Turkey would wait only for so long for its European partners to recognize this. "Turkey is patiently waiting" the then Foreign Minister and current Prime Minister Davutoğlu wrote, "for the EU to appreciate its indispensible position with regard to energy security" (Davutoğlu, 2008, p. 92).

The most critical aspect of the debate over the years has been the energy chapter of the acquis, which remains blocked due to Cyprus' veto. In 2009, the 
then Prime Minister and current President Erdoğan voiced his government's frustration that the energy chapter is blocked despite Turkey's support for Nabucco project. He cautioned the EU that the Turkish government would reconsider its support for Nabucco, unless negotiations commence on the energy chapter (Hurriyet, 2009). Over the last decade, Turkey indeed reformed many of its energy laws and regulations to meet EU standards. With regard to the liberalization and restructuring of the energy markets, Turkish government passed the new Electricity Market Law and Natural Gas Market Law. Turkey also made considerable strides on renewable energy and the adoption of the sections of the EU law for the use of nuclear energy. Given the progress Turkey has made on the adoption of the EU standards laid out in the energy chapter, the fact that the chapter remains closed is a major source of disappointment in Turkish policy circles (Daily Sabah, 2014).

In May 2012, the EC launched the "positive agenda" in EU-Turkey relations with the aim to "keep the accession process of Turkey going and put it back on track after a period of stagnation" (European Commission, 2012). A critical item on the agenda was to find a way around the Cypriot veto. Despite the fact that the EU officials repeatedly emphasized that the positive agenda was not meant to replace the accession process, many Turkish policy makers perceived it as "an attempt to dissociate energy cooperation from the thorny issue of Turkey's accession to the EU" (Koranyi \& Sartori, 2014, p. 31). Similarly, Turkey's refusal to join the Energy Community is indicative of the sensitivities of the Turkish decision makers regarding the perceived linkage between energy and accession issues. Turkey-along with Norway, Georgia and Armenia-has an observer status only in the Energy Community, which aims to extend the energy acquis to Southeast Europe. Turkey and the EU, in fact, were engaged in negotiations in 2009 for Turkey's full membership in the Energy Community; yet the negotiations failed primarily due to Turkey's objection that this arrangement "may suit countries that are not eligible for membership, but not an EU candidate" (Koranyi \& Sartori, 2014, p. 31).

Turkey's relevance for the EU's energy interests is hardly lost on European officials. In 2007, Carl Bildt and Massimo D'Alema (Swedish and Italian foreign ministers) openly sided with Turkey in an op-ed where they called Turkey "a key actor in the realm of energy security" (Bildt \& D'Alema, 2007). EU's coordinator for Nabucco, Jozias van Arsten, went so far as to call Nabucco "a stepping stone towards Turkey's EU membership” (Müftüler-Baç \& Başkan, 2011, p. 372). EU Commissioner Jose Manuel Barroso said, "Turkey should not be seen as a burden, but an asset" (Vucheva, 2009). Nonetheless, support for the energymembership linkage is not universal in European circles. Energy Commissioner 
Andris Piebalgs, for instance, noted that the energy cooperation between the EU and Turkey "is a process that [...] has nothing to do with the EU accession - one does not prejudge the other" (Tekin \& Williams, 2011, p. 172). Having studied the elite perceptions towards Turkey within the EU, Tekin \& Williams (2011, p. 166) find evidence of "both linkage and delinking strategies regarding Turkey's energy role and its accession processes in the current discourse in Europe."

The absence of a unified position within the EU regarding Turkey's role in European energy policy, and what (if any) political payoffs that this role should be expected to generate, is a major obstacle in front of establishing a more comprehensive partnership between Turkey and the EU. The apparent lack of trust between the EU and Turkey, combined with the prevalence of national energy interests over communal ones, prevents the two sides from fully and credibly committing to regional cooperation on energy.

\section{Conclusion}

This article raised three main points. First, the energy platform of the EaP represents the most recent attempt of the EU to tackle one of the most critical problems that it faces today: energy security. Second, Turkey as an independent regional actor has a lot to offer to the EU's diversification efforts not only because Turkey is a natural energy transit corridor but also because Turkey has significant political capital and economic ties in the Caspian that the EU needs to capitalize on in order to achieve integration with the region. Third, despite the apparent convergence of European and Turkish interests, energy relations between the two actors have proved rather knotty over the last decade. This article argued that this is primarily due to a problem of credible commitment, whereby neither party fully and credibly commits to regional energy cooperation. Intra-EU conflicts of interest stemming from variations in import dependency, differences in bargaining leverage based on market size, and the vested interests of major energy companies, have prevented the EU from speaking in a clear and unified voice with its regional partners on energy. Similarly, Turkey prioritized its own short-term energy interests over the prospects of long-term cooperation. The problem has been amplified by the perception on the Turkish side that its cooperative efforts should yield tangible political benefits, most notably in terms of Ankara's bid for EU membership - an expectation, which the EU has been unable to meet.

For the EU and Turkey to realize their full potential as regional energy partners, both sides will need to start placing a higher premium on the long-term benefits 
from cooperation rather than myopic interests. Open and constructive dialogue on the potential political payoffs of energy cooperation for both Turkey and the EU would allow them to recalibrate their expectations, thus rendering cooperation more likely. With Turkey on its side, the EU will find it easier to reach out to the Caspian partners and achieve the energy security related objectives of the EaP. Similarly, Turkey will benefit from a more extended partnership with the EU with regard to its own relations with the EaP countries, as well as its ambitions to become a major energy transit state.

Tolga Demiryol is assistant professor of Political Science in the School of Economics and Administrative Sciences at Istanbul Kemerburgaz University in Turkey. Tolga Demiryol received his Ph.D. in Political Science from the University of Virginia in 2010. Dr. Demiryol specializes in international political economy and security. His recent research focuses on the geopolitics of energy.

\section{References}

Antreasyan, A. (2013), 'Gas Finds in the Eastern Mediterranean: Gaza, Israel, and Other Conflicts,' Journal of Palestine Studies, vol. 42, no. 3, pp. $29-47$.

Baran, Z. (2008), Security Aspects of the South Stream Project, Washington, D.C.: Center for Eurasian Policy, Hudson Institute. Retrieved from http://spp.hudson. org/files/publications/Baran-South\%20Stream\%20for\%20EP.pdf [accessed 25 Feb 2013]

Barroso, J. M. D. (2009), Statement of President Barroso following the Southern Corridor Summit, SPEECH/09/230, European Commission, 8 May 2009. Retrieved from http://europa.eu/rapid/press-release_SPEECH-09-230_en.htm?locale=en [accessed 15 May 2014]

BBC News (2014), "Norway's Statoil in Russian deal," 18 August 2014. Retrieved from http://www.bbc.com/news/world-europe-28843794 [accessed 1 Sep 2014]

Belkin, P.; Nichol, J. \& Woehrel, S. (2012), "Europe's Energy Security: Options and Challenges to Natural Gas Supply Diversification." Retrieved from https://opencrs.com/document/R42405/2012-03-13/download/1005/ [accessed 12 Nov 2012]

Bildt, C. \& D'Alema, M. (2007), "It's Time for a Fresh Effort," The New York Times, 31 August 2007. Retrieved from http://www.nytimes.com/2007/08/31/ opinion/31iht-edbildt.4.7335844.html [accessed 11 Feb 2013] 
Bilgin, M. (2010), “Turkey's energy strategy: What difference does it make to become an energy transit corridor, hub or center?" UNISCI Discussion Papers, no. 23, pp. 113-128.

BOTAS (2011), BOTAS Stratejik Plan, 2010-2014 [BOTAS Strategic Plan, 2010-2014], Ankara, Turkey. Retrieved from http:/www.botas.gov.tr/icerik/docs/ StratejikPlanTR.pdf [accessed 14 Feb 2013]

BP (2012), BP Statistical Review of World Energy 2012. Retrieved from http://www. bp.com/statisticalreview [accessed 16 Jun 2014]

Daily Sabah (2014), "It's time for the EU to open the energy chapter with Turkey," dailysabah.com, 27 August 2014. Retrieved from http:/www.dailysabah.com/ opinion/2014/08/27/its-time-for-the-eu-to-open-the-energy-chapter-with-turkey [accessed 1 Sep 2014]

Davutoğlu, A. (2008), “Turkey’s Foreign Policy Vision: An Assessment of 2007," Insight Turkey, vol. 10, no. 1, pp. 77-96.

Demiryol, T. (2013), 'The Geopolitics of Energy Cooperation between Turkey and the European Union,' L'Europe en Formation, vol. 367, no. 1, pp. 109-134. http://dx.doi.org/10.3917/eufor.367.0109

Directorate of Natural Gas Markets (2012), Dogalgaz Piyasasi 2011 Yili Sektor Raporu [2011 Natural Gas Sectoral Report], Ankara: Turkish Republic Energy Markets Regulatory Authority. Retrieved from http://www.epdk.gov.tr/ documents/dogalgaz/rapor_yayin/Dpd_Rapor_Yayin_Sektor_Raporu_2011_ YML4K810nps7.pdf [accessed 27 Dec 2013]

EIA (2013), Iraq Country Analysis Brief. Retrieved from http://www.eia.gov/countries/ analysisbriefs/Iraq/iraq.pdf [accessed 9 Mar 2014]

Eissler, E. R. \& Arasıl, G. (2014), 'Maritime Boundary Delimitation in the Eastern Mediterranean,' The RUSI Journal, vol. 159, no. 2, pp. 74-80.

Emerson, M. (2013), 'Fishing for Gas in Cypriot Waters,' Insight Turkey, vol. 15, no. 1, pp. $165-181$.

EU at the UN (2009), Declaration: Prague Summit - Southern Corridor, European Union Delegation at the United Nations, 8 May 2009. Retrieved from http://www.eu-un. europa.eu/articles/en/article_8715_en.htm [accessed 15 May 2014]

Eurogas (2013), Long-Term Outlook for Gas to 2035. Retrieved from http://www. eurogas.org/uploads/media/Eurogas_Brochure_Long-Term_Outlook_for_gas_ to_2035.pdf [accessed 24 Jun 2014]

European Commission (2006), Green Paper: A European Strategy for Sustainable, Competitive and Secure Energy, COM(2006) 105 final: European Commission Directorate-General for Energy and Transport, 8 March 2006.

(2008), European Energy and Transport, Trends to 2030 - Update 2007: European Commission Directorate-General for Energy and Transport, 8 April 2008. 
(2011), Energy 2020 - A strategy for competitive, sustainable and secure energy, COM(2010) 639: European Commission Directorate-General for Energy and Transport, 10 November 2010.

(2012), 'Positive Agenda a Bridge Towards Accession Negotiations with Turkey,' 26 June 2012. Retrieved from http://ec.europa.eu/commission_2010-2014/fule/ headlines/news/2012/05/20120518_en.htm [accessed 28 Aug 2014]

(2014a), European Energy Security Strategy, COM (2014) 330: European Commission Directorate-General for Energy and Transport, 28 May 2014.

(2014b), In-depth Study of European Energy Security, SWD (2014) 330: European Commission Directorate-General for Energy and Transport, 2 June 2014.

European Union (2009), Joint Declaration of the Prague Eastern Partnership Summit, 8435/09 Presse 78, Council of the European Union, 7 May 2009. Retrieved from http://ec.europa.eu/europeaid/where/neighbourhood/eastern_partnership/ documents/prague_summit_declaration_en.pdf [accessed 15 May 2014]

Eurostat (2014), Energy Statistics. Retrieved from http://epp.eurostat.ec.europa.eu/ portal/page/portal/energy/data/database [accessed 1 Jul 2014]

Fitch Ratings (2014), Living Without Russian Gas Part 2: Replacing Russian Supplies in the Long Term. Retrieved from www.fitchratings.com [accessed 28 Aug 2014]

Forbes (2014), 'Secure Iranian Gas For Europe,' 7 May 2014. Retrieved from http:/www.forbes.com/sites/michaellynch/2014/05/07/secure-iranian-gas-foreurope/ [accessed 22 Aug 2014]

Foreign and Commonwealth Office (2014), 'Foreign Secretary William Hague announces intention to re-open the British Embassy in Tehran,' Statement on UK/Iran Relations, 17 June 2014. Retrieved from https:/www.gov.uk/government/speeches/statementon-ukiran-relations [accessed 22 Aug 2014]

Gereben, Á. (2013), “Russia’s Energy Weapon,” Hungarian Review, no. 1, pp. 33-40. Haberler (2009), "Enerji Bakani Taner Yildiz: 'Nabucco ile AB'yi Coktan Hak Ettik"” [Minister of Energy Taner Yildiz: 'With Nabucco, We Already Deserve (to be a member of) EU'], 22 August 2009. Retrieved from http://www.haberler.com/ enerji-bakani-taner-yildiz-nabucco-ile-ab-yi-haberi/ [accessed 16 Dec 2012]

Hurriyet (2009), 'Turkey says to review Nabucco project if energy chapter blocked,' 19 January 2009. Retrieved from http://www.hurriyet.com.tr/english/ finance/10808645.asp [accessed 5 Mar 2014]

IEA (2008), Perspectives on Caspian Oil and Gas Development, Paris: International Energy Agency, pp. 1-69.

Iseri, E. \& Andrikopoulos, P. (2013), "Energy Geopolitics of the Eastern Mediterranean: Will Aphrodite's Lure Fuel Peace in Cyprus?” Ortadogu Analiz, vol. 5, no. 51, pp. $37-46$.

Kardaş, Ş. (2012), 'Turkey-Russia Energy Relations: The Limits of Forging Cooperation through Economic Interdependence,' International Journal: 
Canada's Journal of Global Policy Analysis, vol. 67, no. 1, pp. 81-100. http://dx.doi.org/10.1177/002070201206700107

Khadduri, W. (2012), 'East Mediterranean Gas: Opportunities and Challenges,' Mediterranean Politics, vol. 17, no. 1, pp. 111-117.

Kim, Y. \& Blank, S. (2012), 'Russo-Turkish Divergence (Part II); The Energy Dimension,' The Middle East Review of International Affairs (MERIA) Journal, vol. 16. Retrieved from http://www.gloria-center.org/2012/11/russo-turkishdivergence-part-ii-the-energy-dimension-2/ [accessed 5 Mar 2013]

Koranyi, D. \& Sartori, N. (2014), 'EU-Turkey Energy Relations in the Context of EU Accession Negotiations: Focus on Natural Gas,' in Global Turkey in Europe II: Energy, Migration, Civil Society and Citizenship Issues in Turkey-EU Relations, Roma: Edizioni Nuova Cultura, pp. 23-41.

Müftüler-Baç, M. \& Başkan, D. (2011), 'The Future of Energy Security for Europe: Turkey's Role as an Energy Corridor,' Middle Eastern Studies, vol. 47, no. 2, pp. 361-378. http://dx.doi.org/10.1080/00263206.2010.481176

Pointvogl, A. (2009), 'Perceptions, realities, concession-What is driving the integration of European energy policies?’ Energy Policy, vol. 37, no. 12, pp. 5704-5716.

Roberts, J. (2003), 'The Turkish gate: Energy transit and security issues,' Turkey in Europe Monitor, p. 98.

Sidar, C. \& Winrow, G. (2011), 'Turkey and South Stream: Turco-Russian Rapprochement and the Future of the Southern Corridor,' Turkish Policy Quarterly, vol. 10 , no. 2 , pp. 51-61.

Stegen, K. (2011), “Deconstructing the 'Energy Weapon': Russia's Threat to Europe as Case Study," Energy Policy, vol. 39, no. 10, pp. 6505-6513. http://dx.doi. org/10.1016/j.enpol.2011.07.051

Tekin, A. \& Williams, P. A. (2011), Geo-politics of the Euro-Asia Energy Nexus: the European Union, Russia and Turkey, Basingstoke: Palgrave Macmillan.

The Bosnia Times (2014), 'Iran to provide Europe with alternative to Russian gas,' 13 August 2014. Retrieved from http://www.thebosniatimes.com/en/iran-provideeurope-alternative-russian-gas/ [accessed 20 Aug 2014]

The Guardian (2014), “BP's risky Rosneft relationship: 'We work in countries with ups and downs,", The Guardian, 31 July 2014. Retrieved from http://www. theguardian.com/business/2014/jul/31/bp-risky-rosneft-russia-relationship-workin-countries-ups-and-downs [accessed 1 Sep 2014]

The Telegraph (2014), 'Iran offers Europe gas amid Russian energy embargo fears,' 4 May 2014. Retrieved from http://www.telegraph.co.uk/finance/newsbysector/ energy/10808037/Iran-offers-Europe-gas-amid-Russian-energy-embargo-fears. html [accessed 22 Aug 2014] 
Vucheva, E. (2009), 'Turkey May Rethink Nabucco if EU Talks Stall,' EUobserver, 19 January 2009. Retrieved from http://euobserver.com/enlargement/2743 [accessed 4 Jun 2012]

Waltz, K. N. (1970), 'The Myth of National Interdependence,' in The International Corporation, Cambridge, MA: MIT Press.

Winrow, G. (2013), “The Southern Gas Corridor and Turkey's Role as an Energy Transit State and Energy Hub," Insight Turkey, vol. 15, no. 1, pp. 145-163.

Yazar, Y. \& Erkaya, H. H. (2007), “Whither Turkey's Energy Policy?” Insight Turkey, vol. 9, no. 4, pp. 7-22.

Youngs, R. (2011), Energy Security: Europe's New Foreign Policy Challenge, New York: Routledge. 